\title{
The Appearance of a Leptin Effect on Glucose Absorption in Caco2 Cells Depends on Their Differentiation Level
}

\author{
Ola El-Zein Julnar Usta Sawsan Ibrahim Kreydiyyeh \\ Department of Biology, Faculty of Arts \& Sciences, American University of Beirut, Beirut, Lebanon
}

\author{
Key Words \\ Leptin $\bullet \mathrm{Na}^{+} / \mathrm{K}^{+}$ATPase $・$ Caco-2 $\bullet$ Leptin receptors $• \mathrm{SGLT} 1 \cdot \mathrm{GLUT}-2$
}

\begin{abstract}
Backdround/Aims: The aim of this work was to study the effect and mechanism of action of leptin added apically, on glucose absorption, using Caco-2 cells as a model. Methods: Cells were grown on inserts and treated with leptin, at different time points after confluence. Radiolabelled glucose was added to the upper chamber and samples from the lower chamber were collected and assayed for radioactivity. Results: Glucose absorption increased with an increase in the level of differentiation and was associated with an increase in the protein expression level of glucose transporters. Leptin reduced glucose absorption only by day 16 after confluence, the time at which apical leptin receptors started appearing. This inhibitory effect became higher the longer the post confluence period, and was prominent on day 23. The hormone effect was found to be mediated via a decrease in the number of glucose transporters (SGLT1 and GLUT2) and a decrease in the activity of the $\mathrm{Na}^{+} / \mathrm{K}^{+}$ATPase which was assayed by measuring the amount of inorganic phosphate liberated in presence and absence of enzyme activators. Conclusion: It was concluded that by day 23 post confluence, Caco-2 cells are differentiated and are appropriate to use as a model for intestinal transport studies.
\end{abstract}

Copyright $(2015$ S. Karger AG, Basel

\section{Introduction}

Leptin has recently been shown to be produced by the stomach, and its receptors have been identified in intestinal absorptive cells [1-3]. These findings support the idea that leptin may play a role in modulating nutrient absorption and probably glucose. Few studies have tested this hypothesis and those which did, relied on intestinal loops or Ussing chambers [46] which have many experimental limitations. This is why we opted in this work to investigate 
the effect of leptin on glucose absorption using Caco-2 cells which provide a valuable and well recognized model for transport studies, in isolation of other components of the gut. These cells are cancerous colonocytes which grow in continuous polarized monolayers, undergo spontaneous differentiation in long-term culture, and acquire several of the characteristics of normal enterocytes [7-9]. Upon differentiation, they express enzymes and transporters of the small intestine like the PepT1 transporter, $\mathrm{Na}^{+} / \mathrm{H}^{+}$transporter, folate receptor $1, \mathrm{Na}^{+}-$ dependent vitamin $\mathrm{C}$ transporter, basolateral Fe exporter, and others [8, 10-15].

Intestinal glucose absorption is dependent on two families of carriers which ensure the proper delivery of glucose to the blood stream. These are the $\mathrm{Na}^{+}$-dependent glucosetransporters (SGLTs) present on the apical membrane (Wright, 2001) and the facilitative $\mathrm{Na}^{+}$-independent glucose transporters (GLUTs) identified on both the mucosal and serosal sides [16-18]. The energy needed to drive glucose entry via SGLT1 against its concentration gradient is provided by the $\mathrm{Na}^{+}$electrochemical gradient created by the $\mathrm{Na}^{+} / \mathrm{K}^{+}$ATPase present in the basolateral membrane [19-21]. The accumulated sugar within the enterocytes leaves across the basolateral membrane via a facilitative transport process involving GLUT2 [22]. Thus both, glucose transporters and $\mathrm{Na}^{+} / \mathrm{K}^{+}$ATPase, may modulate glucose transport across the intestine.

The aim of this work was, to investigate the effect of leptin on glucose absorption by Caco- 2 cells at different differentiation levels, and to identify its mode of action.

\section{Materials and Methods}

\section{Materials}

Human leptin was purchased from Biovision, CA, USA. Rabbit anti-Na ${ }^{+} / \mathrm{K}^{+}$ATPase $\alpha 1$ polyclonal antibody was purchased from Upstate Biotechnology, NY, USA. Rabbit anti-GLUT2 and anti-SGLT1 polyclonal antibodies were purchased from Chemicon International, CA, and USA. Rabbit anti-Ob-R polyclonal antibody and anti-rabbit IgG horse raddish peroxidase (HRP) conjugated were purchased from Santa Cruz, CA, USA. Protease inhibitors cocktail tablets were purchased from Boehringer Mannheim, Germany. Enhanced Chemiluminescence (ECL) kit was obtained from Santa Cruz, CA, USA. Nitrocellulose membranes, Biorad protein assay reagent and rainbow marker were purchased from Biorad, California, USA. Dulbecco's Minimal Essential Medium (DMEM) with 4500mg/L Glucose and pyridoxine HCL, Fetal Bovine Serum (FBS), Penicillin/Streptomycin (PS), Trypsin-EDTA, 10x Phosphate Buffered Saline (PBS) without calcium and magnesium were purchased from Sigma, Chemical CO, St. Louis, Missouri, USA. Transwell permeable supports (0.4 $\mu \mathrm{m}$-pore-sizes, $24 \mathrm{~mm}$-diameter, and polyester) were purchased from Corning, MA, U.S.A. Scintiverse BD Cocktail was purchased from Fisher Scientific, Fairlawn, NJ, USA. 3-O-methyl-D-glucose $\left(\left[{ }^{14} \mathrm{C}\right]\right.$ 30MG) and Mannitol, D-[1- $\left.{ }^{3} \mathrm{H}(\mathrm{N})\right]$ were bought from Amersham International Ltd. Amersham, UK. The human colon carcinoma cell line (Caco-2) was purchased from American Type Culture Collection (ATCC), VA, USA.

Culture and treatment of Caco-2 Cells

Caco- 2 cells were used at passages 25-35. They were grown in DMEM containing 4500mg/L Glucose, sodium pyruvate, $1 \%$ Penicillin $(100 \mu \mathrm{g} / \mathrm{ml})$, streptomycin $(100 \mu \mathrm{g} / \mathrm{ml})$, supplemented with $10 \% \mathrm{FBS}$, and kept in a humidified incubator $\left(95 \% \mathrm{O}_{2}, 5 \% \mathrm{CO}_{2}\right)$ at $37^{\circ} \mathrm{C}$. The cells were plated at a density of 120,000 cells / $\mathrm{ml}$ and treated on different days after confluence following an overnight starvation.

Caco- 2 cells were treated with different concentrations of leptin, at different time points post confluence. The vehicle was added to the control plates in the same amount and for the same duration. At the end of the incubation period, the plates were washed twice with PBS buffer (pH 7.4) and the cells lysed and homogenized in a polytron (20000-22000 rpm) at $4^{\circ} \mathrm{C}$ after addition of protease inhibitors. Proteins were quantified in the homogenized cells using the Bio-Rad assay, which is based on the Bradford method.

Effect of leptin on glucose absorption by Caco-2 cells

Caco-2 cells were grown on transwell inserts. To determine the hormone effect at different levels of differentiation, the cells were treated with leptin at different time intervals after confluence. Leptin (10 


\section{Cellular Physiology Cell Physiol Biochem 2015;37:491-500 \begin{tabular}{ll|l} 
and Biochemistry & $\begin{array}{l}\text { DOI 10.1159/000430371 } \\
\text { Published online: August 28, } 2015\end{array}$ & $\begin{array}{l}\text { O 2015 S. Karger AG, Basel } \\
\text { www.karger.com/cpb }\end{array}$ \\
\cline { 2 - 3 }
\end{tabular} \\ El-Zein et al.: Leptin Inhibits Glucose Absorption in Differentiated Caco-2 Cells}

$\mathrm{nM})$ was added to the upper chamber together with $3-0-{ }^{14} \mathrm{C}$ methyl $\mathrm{D}$ glucose $\left(\left[{ }^{14} \mathrm{C}\right] 3 \mathrm{OMG}\right)(0.3 \mu \mathrm{M}, 2.087$ GBq mmol $\left.{ }^{-1}\right)$ and D-mannitol-[1- $\left.{ }^{3} \mathrm{H}(\mathrm{N})\right]\left(0.44 \mathrm{nM}, 455.1 \mathrm{GBq} \mathrm{mmol}^{-1}\right)$. The latter was used to check for the integrity of the Caco-2 cell monolayer and to confirm junctional tightness. The Permeability indices obtained ranged between $6.6 \times 10^{-10} \mathrm{~cm} \mathrm{~s}^{-1}$ and $9.5 \times 10^{-8} \mathrm{~cm} \mathrm{~s}^{-1}$. Monolayers with an index higher than 5 x $10^{-7} \mathrm{~cm} \mathrm{~s}^{-1}$ were considered leaky and were discarded (Hubatsch et al., 2007). Glucose absorption was calculated as the difference in radioactivity of samples collected from the lower chamber before and $50 \mathrm{~min}$ after addition of the radioactive tracers, standardized to unit surface area.

\section{$\mathrm{Na}^{+} / \mathrm{K}^{+}$ATPase Activity}

$\mathrm{Na}^{+} / \mathrm{K}^{+}$ATPase activity was assayed as described by Esmann [23]. Samples of cell homogenates were incubated with ATP $(2.94 \mathrm{mM})$ for $30 \mathrm{~min}$ at $37^{\circ} \mathrm{C}$ in presence and absence of $\mathrm{KCl}(19.6 \mathrm{mM})$, NaCl (121.52 mM), and MgCl2 (3.92 mM). The reaction was stopped by addition of trichloroacetic acid (50\%) and samples were spun at $3000 \mathrm{~g}$ for $5 \mathrm{~min}$. The amount of inorganic phosphate liberated in the supernatant was measured colorimetrically using an ELISA reader at $750 \mathrm{~nm}$ according to the method of Taussky and Shorr [24]. Enzymatic activity was determined by calculating the difference in inorganic phosphate liberated in the presence and absence of the activators $\left(\mathrm{Na}^{+}, \mathrm{K}^{+}\right.$and $\left.\mathrm{Mg}^{++}\right)$. Results are reported as percent of control values.

\section{Isolation of Apical and Basolateral Membrane Fractions}

The isolation was performed as described by Ellis et al. [25]. All steps were carried out at $4^{\circ} \mathrm{C}$. Cells were collected, homogenized in a polytron, suspended in buffer A $(250 \mathrm{mM}$ sucrose $/ 12 \mathrm{mM}$ Tris- $\mathrm{HCl}, \mathrm{pH}$ 7.4) and spun at $270 \mathrm{x}$ g for $5 \mathrm{~min}$. The resulting supernatant (1) was collected and centrifuged for $10 \mathrm{~min}$ at $920 \mathrm{x}$ g. To the new supernatant (2), $\mathrm{MgCl} 2$ was added to a final concentration of $10 \mathrm{mM}$ while stirring on ice for $15 \mathrm{~min}$. The resulting supernatant (3) obtained was spun in an ultra-centrifuge at $170000 \mathrm{xg}$ for $45 \mathrm{~min}$, thus giving a crude membrane pellet (4) which was re-suspended in buffer B (250 mM sucrose/ 5 $\mathrm{mM} \mathrm{Na}_{2} \mathrm{EDTA} / 12 \mathrm{mM}$ Tris-HCl, $\mathrm{pH} 7.4$ ) and layered on a discontinuous sucrose density gradient (w/w): $1.41 \mathrm{ml}, 45 \% ; 1.64 \mathrm{ml}, 35 \% ; 1.42 \mathrm{ml}, 30 \%$; the sucrose solutions were prepared using $10 \mathrm{mM}-\mathrm{Tris} / \mathrm{HCl}, \mathrm{pH}$ 7.4. Centrifugation was at $68000 \mathrm{xg}$ for $4.5 \mathrm{~h}$. The bands at the interfaces (assigned as fractions: I, overlay / $30 \%$; II, 30\% / $35 \%$; III, 35\% / 45\%) were collected with a needle and diluted with buffer A to $8 \%$ sucrose. Fraction II was spun at $23000 \mathrm{x}$ g for 14 min after addition of $\mathrm{MgCl}_{2}$ on ice, while stirring for $15 \mathrm{~min}$. The resulting supernatant (5) and fractions I and III were separately spun at $36600 \mathrm{xg}$ for $60 \mathrm{~min}$. The pellets from fractions I (Golgi-complex), II (basolateral) and III (apical) were re-suspended in a minimal volume of buffer A. Protein levels in fractions II and III were determined using the Bio-Rad protein assay and subjected to western blot analysis.

\section{Western Blot Analysis}

Equal amounts of proteins of whole homogenates or isolated fractions (apical or basolateral) were loaded, resolved on 8\% SDS polyacrylamide gel and transferred to a nitrocellulose membrane which was then blocked and incubated with a primary $\mathrm{Na}^{+} / \mathrm{K}^{+}$ATPase, SGLT1, GLUT2, or Ob-R antibody followed by an incubation with a goat anti-rabbit secondary IgG conjugated to horse radish peroxidase (HRP). The signal was detected by enhanced chemiluminescence using luminol. Equal loading was checked by GAPDH expression.

\section{Statistical Analysis}

Results are reported as means \pm SEM and tested for statistical significance by a t-test or by a one-way Analysis of Variance (ANOVA) followed by Tukey-Kramer multiple comparisons test using Instat and Excel Analysis softwares.

\section{Results}

Caco-2 cells differentiation and leptin's effect on glucose absorption

Glucose absorption by Caco-2 cells was dependent on the level of differentiation and increased sharply as of day 12 post confluence. 
Leptin inhibited glucose absorption, but this inhibitory effect appeared only after the $12^{\text {th }}$ day post confluence (Fig. 1).

Effect of leptin on the $\mathrm{Na}^{+} / \mathrm{K}^{+}$ATPase activity at different periods post confluence

Similarly, the inhibitory effect of leptin $(10 \mathrm{nM}, 45 \mathrm{~min})$ on the activity of the $\mathrm{Na}^{+} /$ $\mathrm{K}^{+}$ATPase did not appear till day 12 post confluence and increased thereafter to reach a maximum on day 23 , then decreased to disappear completely by the $30^{\text {th }}$ day after confluence (Fig. 2).

Dose and Time response studies on leptin's action on the $\mathrm{Na}^{+} / \mathrm{K}^{+}$ATPase activity in differentiated Caco-2 cells, 23 days after confluence

A dose and time response study on the effect of leptin on the activity of the $\mathrm{Na}^{+} / \mathrm{K}^{+}$ ATPase was conducted on day 23 after confluence, the time point at which the maximal inhibitory effect was observed previously. Leptin caused a significant decrease in the ATPase activity at doses ranging between $5 \mathrm{nM}$ and $25 \mathrm{nM}$ but not at higher ones (40 nM to $100 \mathrm{nM}$ ). At the concentrations assayed, $5 \mathrm{nM}, 7 \mathrm{nM}, 10 \mathrm{nM}, 15 \mathrm{nM}, 20 \mathrm{nM}$ and $25 \mathrm{nM}$, the ATPase activity was reduced by $26 \%, 30 \%, 47 \%, 37 \%, 32 \%$ and $24 \%$ respectively (Fig. $3 \mathrm{a}$ ). At a concentration of $10 \mathrm{nM}$, the decrease in the ATPase activity was also dependent on the duration of the treatment; it was manifested only during the first $60 \mathrm{~min}$, reached its maximum at $45 \mathrm{~min}$ and disappeared completely after one hour (Fig. 3b).

Fig. 1. Effect of leptin $(10 \mathrm{nM})$ on glucose absorption by Caco- 2 cells at different time points post- confluence. Cells were treated with leptin for $50 \mathrm{~min}$. Values are means $\pm \mathrm{SE}$ of 6 observations. Different letters indicate significant differences. Values sharing a common letter are not significantly different from each other. $* \mathrm{P}<0.04,{ }^{* *} \mathrm{P}<0.01$, significantly different from the control.

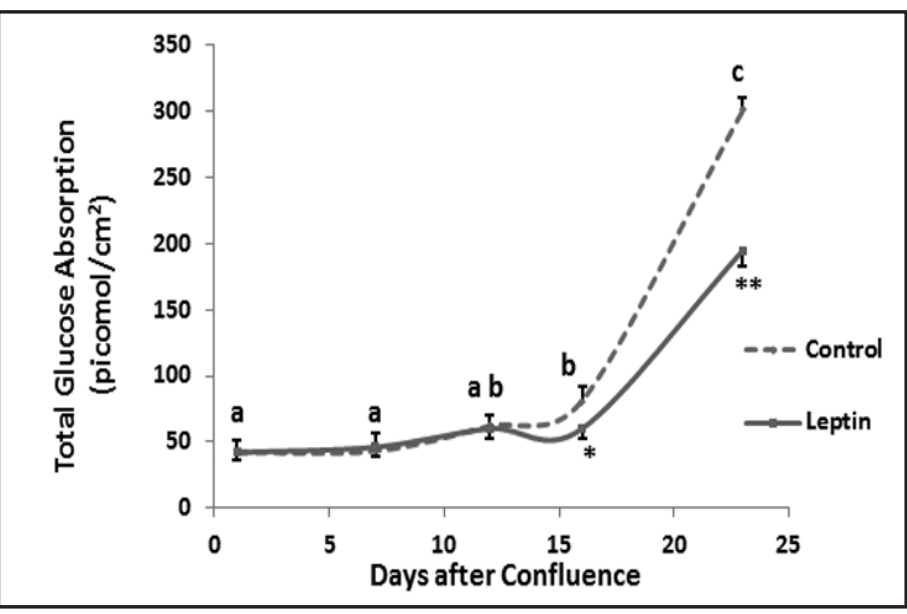

Fig. 2. Effect of leptin $(10 \mathrm{nM})$ on the activity of the $\mathrm{Na}^{+} / \mathrm{K}^{+}$ATPase in Caco- 2 cells at different time points, post confluence. Cells were treated with leptin for $45 \mathrm{~min}$. Values are means \pm SE of 6 observations. * $\mathrm{P}<0.04,{ }^{* *} \mathrm{P}<0.01,{ }^{* * *} \mathrm{P}<0.001$ : significantly different from the control.

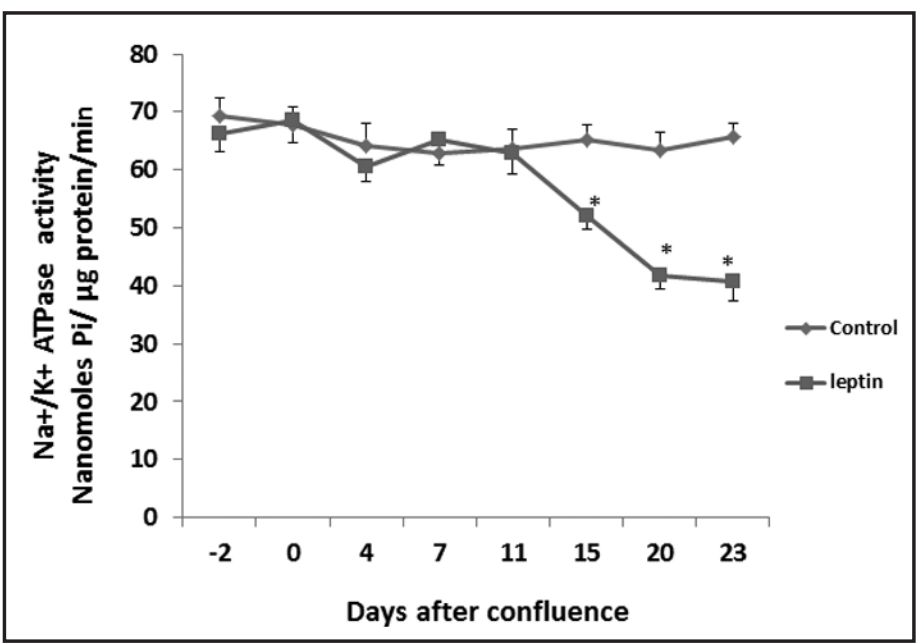


Fig. 3. Dose (a) and time (b) response study on the effect of leptin on the activity of the $\mathrm{Na}^{+} / \mathrm{K}^{+}$ATPase in Caco- 2 cells, at different time periods post confluence. Cells were incubated with leptin for $45 \mathrm{~min}$. Values are means \pm SE of 6 observations. (a) $\neq \mathrm{P}<0.01,{ }^{*} \mathrm{P}<0.005$ : significantly different from the control. (b) $* \mathrm{P}<0.01$, ${ }^{* *} \mathrm{P}<0.003,{ }^{* * *} \mathrm{P}<0.0001$ : significantly different from the control.

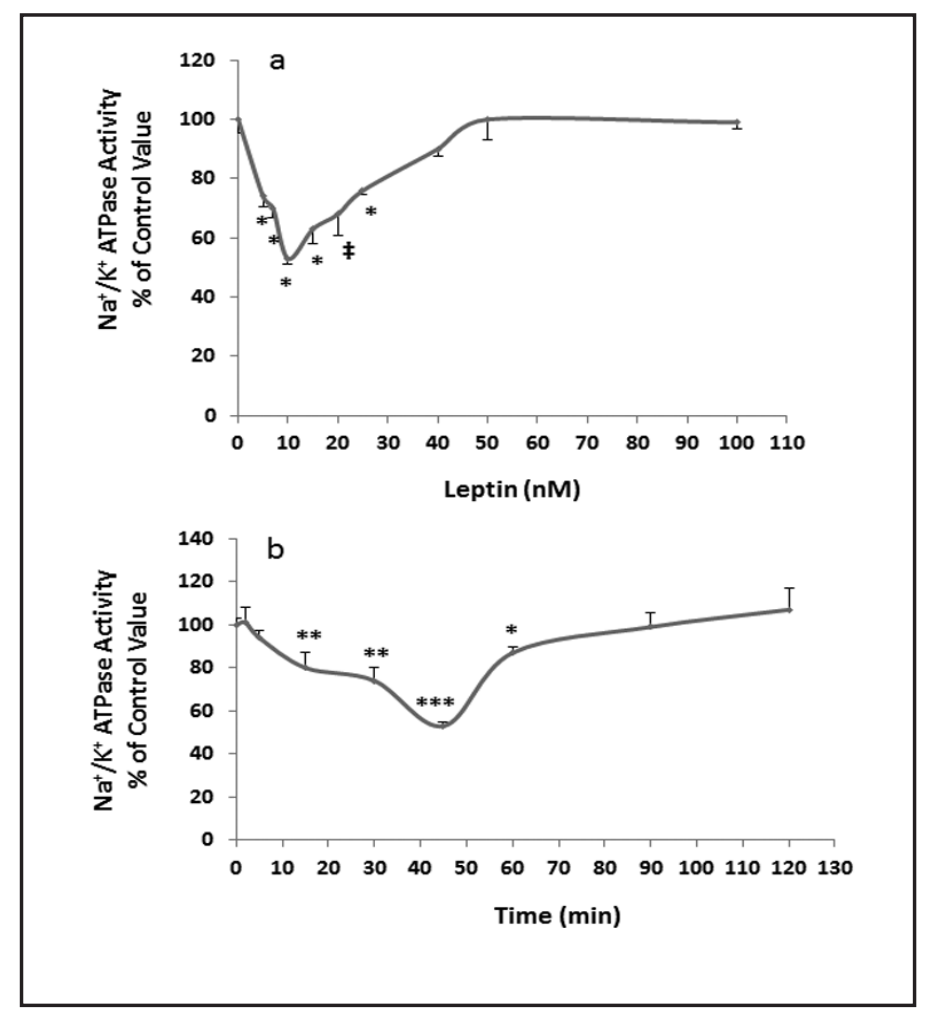

Purity of the isolated apical and basolateral membranes

The purity of the isolated mucosal and serosal membranes was assessed by checking for the protein expression of SGLT1, a transporter present exclusively on the apical side and the expression of the $\mathrm{Na}^{+} / \mathrm{K}^{+}$ATPase, a marker enzyme expressed only in the basolateral membrane. The expression of SGLT1 was 9.3-fold higher in the isolated apical fraction than in the whole homogenate (Fig. 4a) while that of the $\mathrm{Na}^{+} / \mathrm{K}^{+}$ATPase was 21.2 fold higher in the basolateral membrane than in the whole homogenate (Fig 4b). The ATPase was barely detected in brush border membranes (Fig. 4c) and SGLT1 was barely detected in basolateral membranes (Fig. 4d), confirming thus the absence of any contamination.

Effect of differentiation on the apically expressed leptin receptors, SGLT and GLUT2, and on basolaterally expressed GLUT2

The number of leptin receptors in the apical membrane of Caco-2 cells was very low on days 1 and 7 after confluence, but started to increase progressively from day 12 up to day 23 after confluence (Fig. 5a).

At days 1 and 7 after confluence, SGLT1 was barely detected in the apical membrane but became clearly apparent by day 12 and its expression increased further on day 16 and 23 post confluence (Fig. 5b). Changes in the expression of apical and basolateral GLUT2 followed exactly the same trend (Fig. 5c \& d).

Effect of leptin on glucose transporters

Leptin decreased the level of expression of SGLT1 and GLUT2 transporters in the membranes on days 16 and 23 after confluence, with a higher effect on day 23 (Fig. 6).

\section{Discussion}

To appear in blood, luminal glucose has to cross two barriers: the enterocyte brush border membrane via a secondary active transport process mediated by SGLT1 transporters, 


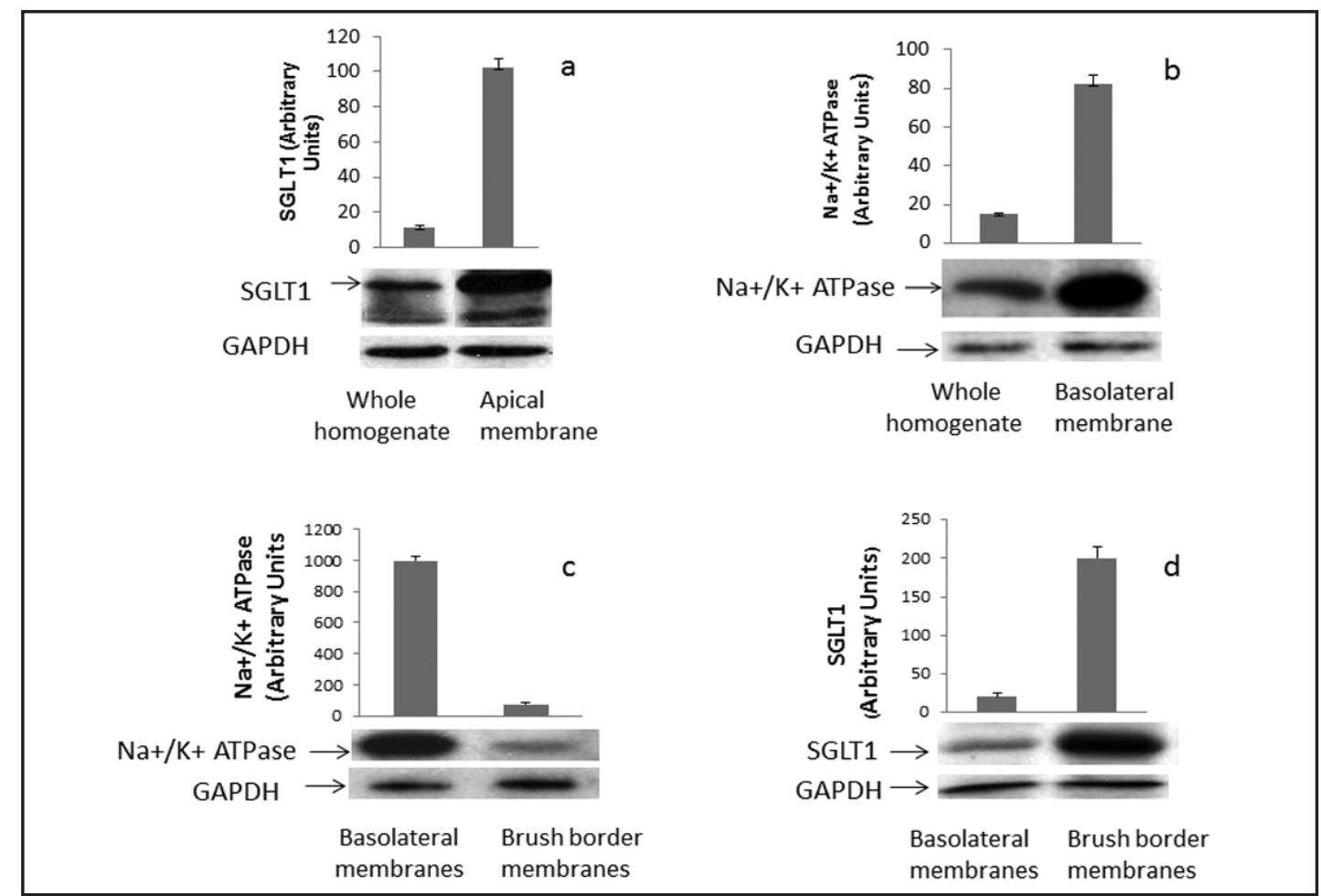

Fig. 4. Enrichment and recovery of markers SGLT1 $(\mathrm{a}, \mathrm{d})$ and $\mathrm{Na}^{+} / \mathrm{K}^{+}$ATPase $(\mathrm{b}, \mathrm{c})$ in the whole homogenate and the purified membranes. (The bands and their quantification values are the result of three independent experiments. Bands were quantified using GelPro 3 analyzer software and represented in arbitrary units. $* \mathrm{P}<0.0001$ : significantly different from its homogenate.

Fig. 5. Expression of apical leptin receptors (a), SGLT1 (b), and GLUT2 (c), and basolateral GLUT2 in Caco-2 cells, at different time periods post confluence. The results of each of (a), (b), (c) and (d) are representative of an experiment repeated 3 times. Bands were quantified using GelPro 3 analyzer software and represented in arbitrary densitometry units.

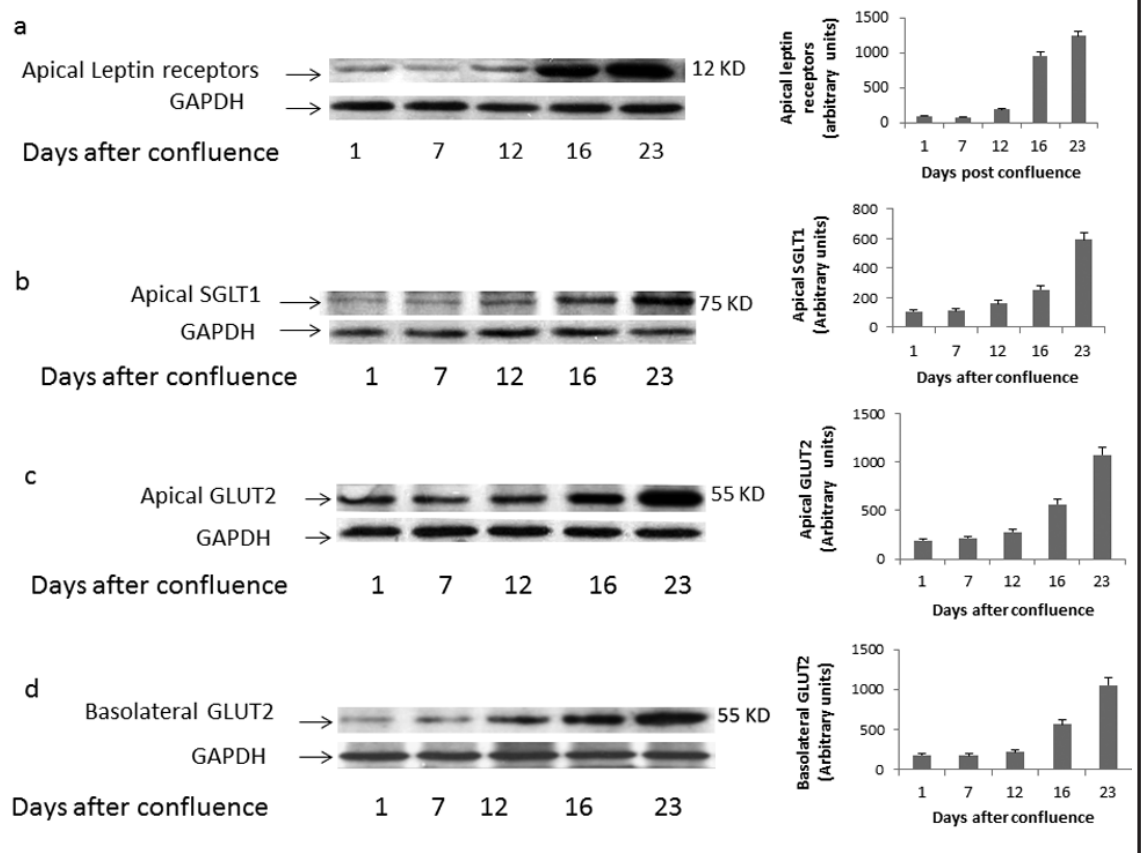

and the basolateral membrane via a passive facilitative process mediated by GLUT2 transporters [22]. GLUT2 was thought previously to be restricted to the basolateral plasma

\section{KARGER}




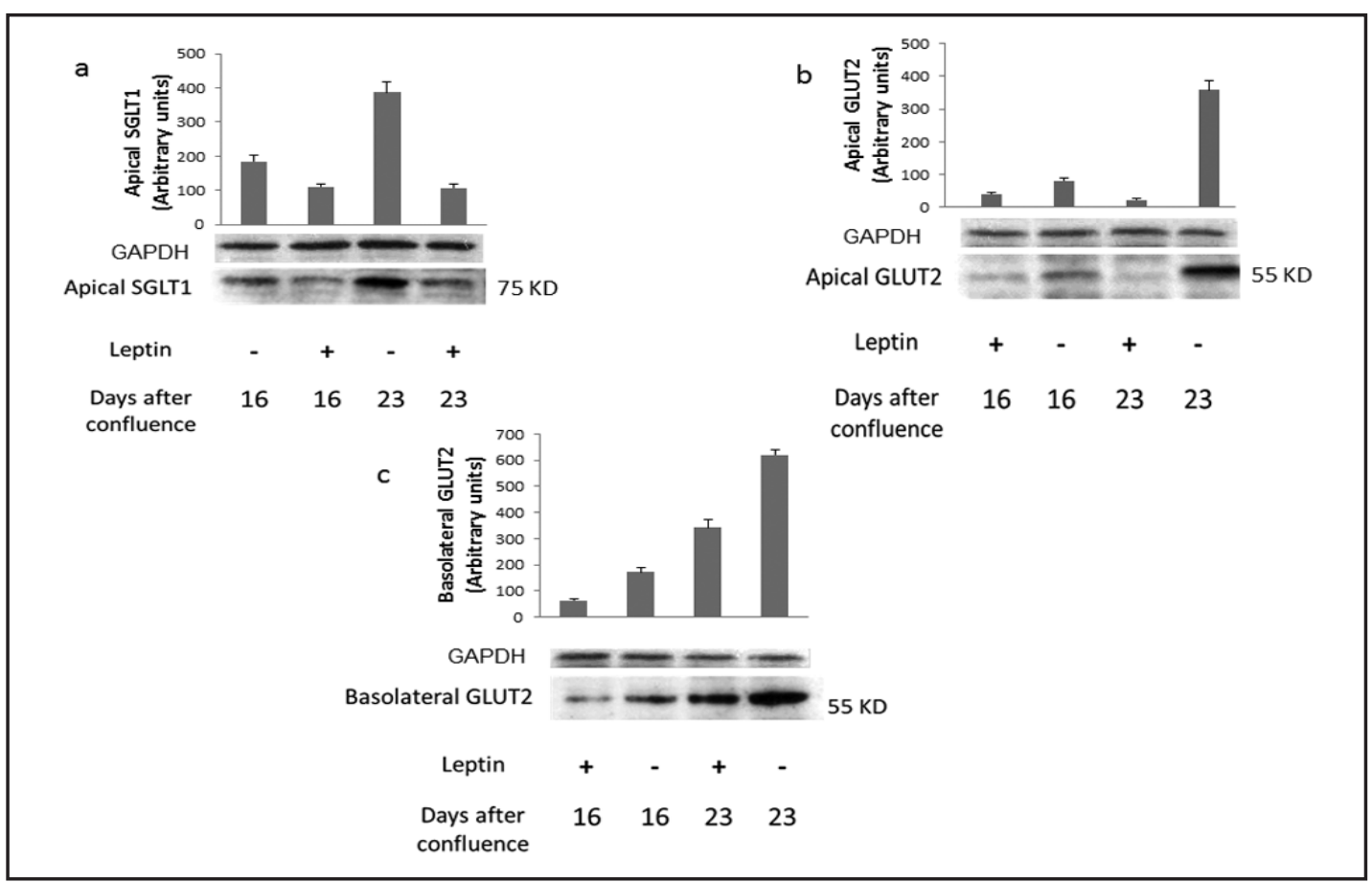

Fig. 6. Effect of leptin (10 nM) on the expression of apical SGLT1, and apical and basolateral GLUT2 in Caco2 cells on days 16 and 23 post confluence. Cells were treated with leptin for $50 \mathrm{~min}$. The results of each of (a), (b) and (c) are representative of an experiment repeated 3 times. Bands were quantified using GelPro 3 analyzer software and represented in arbitrary densitometry units.

membrane [26], but more recent studies showed that the increase in intracellular glucose transported by SGLT1 induces GLUT2 recruitment to the apical side [18].

In this work, glucose absorption was studied using colonic Caco- 2 cells, which are known to differentiate after confluence into cells possessing all the characteristics of enterocytes. Whether glucose uptake by these cells varies with the stage of differentiation is a question that we tried to address by measuring glucose absorption at different time points after confluence.

The total glucose absorbed on days 16 and 23 post confluence was respectively 2 and 7 folds higher than the amount absorbed on day 1 after confluence (Fig. 1), and was accompanied with an increase in the number of SGLT1 and GLUT2 transporters (Fig. 5). Since Caco-2 cells are cancerous colonocytes, they are not expected to express high levels of glucose transporters, as the large intestine is not usually involved in glucose absorption. As the cells differentiate, they acquire the properties of enterocytes and express proteins specific to intestinal cells like hormone receptors and membrane carriers [27].

The effect of leptin on glucose absorption varied at different stages of differentiation. A significant inhibitory effect of the hormone on glucose absorption appeared only as of day 12 post confluence (Fig. 1). The absence of a leptin effect before day 12 may be ascribed to the absence of leptin receptors in the apical membrane. Western blot analysis revealed in fact a very low protein expression of the receptors earlier than day 12 post confluence (Fig. 5 ). Although many studies demonstrated the presence of leptin receptors in colonocytes and enterocytes [3, 28-33], none of them studied in Caco-2 cells the changes in their level at various periods after confluence. One study checked for the expression of these receptors on day 21 post confluence, but it was conducted in a modified intestinal cell line, Caco-2/15 [34]. The receptors identified in our purified brush border membranes had a molecular weight of $\sim 120 \mathrm{kDa}$ indicating that they are of the OB-Rb type, the isoform that is thought to mediate the biological effects of leptin [28, 29]. 


\section{Cellular Physiology Cell Physiol Biochem 2015;37:491-500

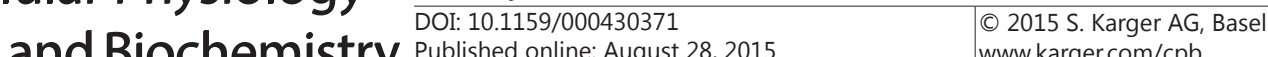

Intestinal glucose absorption is known to be regulated, by the number of glucose transporters and by the sodium gradient created by the $\mathrm{Na}^{+} / \mathrm{K}^{+}$ATPase that gears the transport process [35-37].

The inhibitory effect of leptin on glucose absorption appeared by day 12 post confluence (Fig. 1), and became significant on day 16 and thereafter. Leptin decreased the expression of basolateral GLUT2, and apical SGLT1 and GLUT2 on day 16 and day 23 after confluence (Fig 6). On day 23, glucose absorption was reduced to around $55 \%$ of its control value. The literature reports controversial data on the effect of leptin on sugar absorption. While some studies demonstrated a similar leptin induced inhibition ascribed to a down-regulation of SGLT1 but not GLUT2 [2, 4, 38, 5, 6,], others reported in rat enterocytes, a leptin induced increase in galactose and fructose absorption due to an increase in GLUT2 and GLUT5 [39].

Similar to its effect on glucose absorption, leptin exerted an inhibitory effect on the activity of the $\mathrm{Na}^{+} / \mathrm{K}^{+}$ATPase that was maximal on day 23 (Fig. 2) and was manifested only for $60 \mathrm{~min}$ and at a dose ranging between 5-25 nM (Fig. 3). Leptin thus reduced the sodium gradient that drives glucose transport by SGLT1 transporters. The restriction of leptin response to one hour only may be ascribed to the inhibitory effect of the suppressor of cytokine signaling 3 (SOC-3). SOC-3 has been recognized as an inhibitor of leptin signaling and its production is induced by leptin itself. SOC-3 binds to JAK-2 and attenuates its tyrosine phosphorylation and consequently the transduction of the signal. An increase in SOC-3 mRNA appeared at 30 and $60 \mathrm{~min}$ after treatment in $\mathrm{CHO}$ cells expressing the long form of the leptin receptor [40].

SOC-3 may be also behind the specific range at which leptin effect was observed. Doses lower than $5 \mathrm{nM}$ were probably too low to activate the receptors, and doses higher than 25 $\mathrm{nM}$ elicited the production of a high level of SOC-3 that blocked leptin signaling.

A decrease in the activity of the pump in the control untreated cells was observed at late periods after confluence, that is ascribed to differentiation A reduced $\mathrm{Na}^{+} / \mathrm{K}^{+}$ATPase activity and an increase in intracellular sodium were found to induce cell differentiation in many cell types like adipocytes [41], murine erythroleukemia cells [42], pre-B lymphocyte cells [43] and MDCK cells [44, 45].

The results suggest that the inhibitory effect of leptin on glucose absorption appears only when Caco-2 cells have differentiated and acquired the properties, transporters, and receptors of enterocytes. The hormone reduces glucose absorption by decreasing the activity of the $\mathrm{Na}^{+} / \mathrm{K}^{+}$ATPase and the number of glucose transporters (SGLT1 and GLUT2).

\section{Acknowledgments}

This work was supported by the Lebanese National Council for Scientific Research and the University Research Board.

\section{Disclosure Statement}

The authors declare no conflict of interest.

\section{References}

1 Bado A, Levasseur S, Attoub S, Kermorgant S, Laigneau JP, Bortoluzzi MN, Moizo L, Lehy T, GuerreMillo M, Le Marchand-Brustel Y, Lewin MJ: The stomach is a source of leptin. Nature 1998;394:790-793.

2 Lostao MP, Urdaneta E, Martinez-Anso E, Barber A, Martinez JA: Presence of leptin receptors in rat small intestine and leptin effect on sugar absorption. FEBS Lett 1998;423:302-306. 


\section{Cellular Physiology Cell Physiol Biochem 2015;37:491-500 \begin{tabular}{l|l|}
\cline { 2 - 2 } DOI: 10.1159/000430371 & O 2015 S. Karger AG, Basel
\end{tabular}

3 Barrenetxe J, Villaro AC, Guembe L, Pascual I, Munoz-Navas M, Barber A, Lostao MP: Distribution of the long leptin receptor isoform in brush border, basolateral membrane, and cytoplasm of enterocytes. Gut 2002;50:797-802.

4 Fanjul C, Barrenetxe J, Iñigo C, Sakar Y, Ducroc R, Barber A, Lostao MP: Leptin regulates sugar and amino acids transport in the human intestinal cell line Caco-2. Acta Physiol 2012;205: 82-91.

5 Ducroc R, Guilmeau S, Akasbi K, Devaud H, Buyse M, Bado A: Luminal leptin induces rapid inhibition of active intestinal absorption of glucose mediated by sodium-glucose cotransporter 1 . Diabetes 2005;54:348-354.

6 In igo C, Patel N, Kellett GL, Barber A, Lostao MP: Luminal leptin inhibits intestinal sugar absorption in vivo. Acta Physiol 2007;190:303-310.

7 Pinto M, Robine-Leon S, Appay M D, Kedinger M, Triadou N, Dussaulx E, Lacroix B, Simon-Assmann P, Haffen K, Fogh J, Zweibaum A: Enterocyte-like differentiation and polarization of the human colon carcinoma cell line Caco-2 in culture. Biol Cell 1983;47:323-330.

8 Artursson P: Epithelial transport of drugs in cell culture. I: A model for studying the passive diffusion of drugs over intestinal absorptive (Caco-2) cells. J Pharm Sci 1990;79:476-482.

9 Hidalgo IJ, Raub TJ, Borchardt RT : Characterization of the human colon carcinoma cell line (Caco-2) as a model system for intestinal epithelial permeability. Gastroenterology 1989;96:736-749.

10 10. Behrens I, Kissel T: Do cell culture conditions influence the carrier-mediated transport of peptides in Caco-2 cell monolayers? Eur J Pharm Sci 2003;19:433-442.

11 Bravo S A, Nielsen C U, Amstrup J, Frokjaer S, Brodin B: In-depth evaluation of Gly-Sar transport parameters as a function of culture time in the Caco-2 cell model. Eur J Pharm Sci 2004;21:77-86.

12 Janecki A J, Montrose M H, Tse C M, de Medina F S, Zweibaum A, Donowitz M: Development of an endogenous epithelial $\mathrm{Na}+\mathrm{H}+$ exchanger (NHE3) in three clones of Caco-2 cells. Am J Physiol-Gastrointest Liver Physiol 1999; 277:G292-G305.

13 Fleet J C, Wang L, Vitek O, Craig B A, Edenberg H J: Gene expression profiling of Caco-2 BBe cells suggests a role for specific signaling pathways during intestinal differentiation. Physiol Genom 2003;13:57-68.

14 Maulen NP, Henriquez E., Kempe S, Cárcamo JG, Schmid-Kotsas A, Bachem M, Grünert A, Bustamante ME, Nualart F, Vera JC: Up-regulation and polarized expression of the sodium-ascorbic acid transporter SVCT1 in post-confluent differentiated CaCo-2 cells. J Biol Chem 2003;278:9035-9041.

15 Han 0, Wessling-Resnick M: Copper repletion enhances apical iron uptake and transepithelial iron transport by Caco-2 cells. Am J Physiol Gastrointest Liver Physiol 2002;282:G527-533.

16 Mueckler M: Facilitative glucose transporters. Eur J Biochem 1994;219:713-725.

17 Joost HG, Thorens B: The extended GLUT-family of sugar/polyol transport facilitators: nomenclature, sequence characteristics, and potential function of its novel members. Mol Membr Biol 2001;18:247-256.

18 Kellett GL, Helliwell PA: The diffusive component of intestinal glucose absorption is mediated by the glucose induced recruitment of GLUT2 to the brush-border membrane. Biochem J 2000;350:155-162.

19 Crane RK, Miller D, Bihler I: The restrictions on possible mechanisms of intestinal active transport of sugars; in Kleinzeller A, Kotyk A (eds): Membrane Transport and Metabolism. New York, Academic Press, 1961, vol 1, pp 439-449.

20 Hediger MA, Kanai Y, You G, Nussberger S: Mammalian ion-coupled solute transporters. J Physiol 1995;482:7S-17S.

21 Kwon HM, Yamauchi A, Uchida S, Preston AS, Garcia-Perei A, Burg MB, Handler JS: Cloning of the cDNA for a $\mathrm{Na}+$ /myo-inositol cotransporter, a hypertonicity stress protein. J Biol Chem 1992;267:6297-6301.

22 Uldry M, Thorens B: The SLC2 family or facilitated hexose and polyol transporters. Pflugers Arch 2004;447:480-489.

23 Esmann, E: ATPase and phosphatase activity of $\mathrm{Na}+\mathrm{K}+$-ATPase: molar and specific activity, protein determination; in Fleischer S, Fleischer B (eds): Mehods in Enzymology, London: Academic Press, 1998,Vol 156, pp 105-115.

24 Taussky HH, Shorr E: Microcolorimetric Method for Determination of Inorganic Phosphorous. J. Biol. Chem 1995;202:675-685.

25 Ellis JA, Jackman MR, Luzio JP: The post-synthetic sorting of endogenous membrane proteins examined by the simultaneous purification of apical and basolateral plasma membrane fractions from Caco-2 cells. Biochem. J 1992;283:553-560. 


\section{Cellular Physiology Cell Physiol Biochem 2015;37:491-500 \begin{tabular}{l|l} 
and Biochemistry $\begin{array}{l}\text { Published online: August 28, } 2015 \\
\text { a 2015 S. Karger AG, Basel } \\
\text { www.karger.com/cpb }\end{array}$ \\
\hline
\end{tabular} \\ El-Zein et al.: Leptin Inhibits Glucose Absorption in Differentiated Caco-2 Cells}

26 Thorens B, Cheng Z-Q, Brown D, Lodish HF: Liver glucose transporter: A basolateral protein in hepatocytes and intestine and kidney cells. Am J Physiol 1990;259:C279-C285.

27 Zweibaum A, Laburthe M, Grasset E, LouvardD: Use of cell lines in studies of intestinal cell differentiation and function, in Field M, Frizzel RA (eds): Handbook of physiology, the gastrointestinal system: intestinal absorption and secretion. New York, USA, Oxford University Press. 1991, pp 223-255.

28 Hardwick JC, Van Den Brink GR, Offerhaus GJ, Van Deventer SJ, Peppelenbosch MP: Leptin is a growth factor for colonic epithelial cells. Gastroenterology 2001;121:79-90.

29 Buyse M, Berlioz F, Guilmeau S, Tsocas A, Voisin T, Peranzi G, Merlin D, Laburthe M, Lewin MJM, Roze C, Bado A: PepT1-mediated epithelial transport of dipeptides and cephalexin is enhanced by luminal leptin in the small intestine. J Clin Invest 2001;108:1483-1494.

30 Aparicio T, Kermorgant S, Darmoul D, Guilmeau S, Hormi K, Mahieu-Caputo D, Lehy T: Leptin and Ob$\mathrm{Rb}$ receptor isoform in the human digestive tract during fetal development. J Clin Endocrinol Metab 2005;90:6177-6184.

31 Cammisotto PG, Renaud C, Gingras D, Delvin E, Levy E, Bendayan M: Endocrine and exocrine secretion of leptin by the gastric mucosa. J Histochem Cytochem 2005;53:851-860.

32 Hansen G, Niels-Christiansen L, Danielsen E: Leptin and the Obesity Receptor (OB-R) in the Small Intestine and Colon: A Colocalization Study. J Histochem Cytochem 2008;56:677-685.

33 Morton N.M, Emilsson V, Liu YL, Cawthorne MA: Leptin action in intestinal cells. J Biol Chem 1998;273:26194-26201.

34 Cammisotto, PG, Bendayan M, San'e A, Dominguez M, Garofalo C, Levy E: Receptor-Mediated Transcytosis of Leptin through Human Intestinal Cells In Vitro. Int J Cell Biol DOI:10.1155/2010/928169.

35 Wright EM, Hirsch JR, Loo DDF, Zampighi GA: Regulation of Na+/Glucose Cotransporters. J Exp Biol 1997;200:287-293.

36 Lingrel JB, Kuntzweiler T: Na+,K+-ATPase. J Biol Chem 1994;269:19659-19662.

37 Barrenetxe J, Barber A, Lostao MP: Leptin effect on galactose absorption in mice jejunum. J Physiol Biochem 2001;57:345-346.

38 Therien AG, Blostein R: Mechanisms of sodium pump regulation. Am J of Physiol Cell Physiol 2000;279:C541-C566.

39 Sakar Y, Nazaret C, Letteron P, Ait Omar A, AvenatiM., Viollet B, Ducroc R, Bado A: Positive regulatory control loop between gut leptin and intestinal GLUT2/GLUT5 transporters links to hepatic metabolic functions in rodents. PLoS ONE 2009;4:e7935.

40 Bjørbæk C, El-Haschimi K, Frantz JD, Flier JS: The Role of SOCS-3 in Leptin Signaling and Leptin Resistance. J Biol Chem 1999;274;30059-30065

41 Resh M.D: Development of insulin responsiveness of the glucose transporter and the (Na+, $\mathrm{K}+$ )-adenosine triphosphatase during in vitro adipocyte differentiation. J Biol Chem 1982;257:6978-6986.

42 Smith RL, Macara IG, Levenson R, Housman D, Cantley L: Evidence that a Na+/Ca2+ antiport system regulates murine erythroleukemia cell differentiation. J Biol Chem 1982;257:773-780.

43 Rosoff PM, Cantley LC: Increasing the intracellular Na+ concentration induces differentiation in a pre-B lymphocyte cell line. Proc. Natl Acad Sci USA 1983;80:7547-7550.

44 Kennedy BG, Lever JE: Regulation of Na', K+-ATPase activity in MDCK kidney epithelial cell cultures: Role of growth state, cyclic AMP and chemical inducers of dome formation and differentiation. J Cell Physiol 1984;121:51-63.

45 Kennedy BG, Lever JE: Transport by the $(\mathrm{Na}+\mathrm{K}+)$ ATPase: modulation by differentiation inducers and inhibition of protein synthesis in the MDCK kidney epithelial cell line. J Cell Physiol 1985;123:410-416. 